\title{
Performance and emission characteristics of micro gas turbine engine fuelled with bioethanol-diesel-biodiesel blends
}

\author{
N. Saifuddin ${ }^{1 *}$, H. Refal ${ }^{1}$ and P. Kumaran ${ }^{2}$ \\ ${ }^{1}$ Institute of Sustainable Energy, \\ Universiti Tenaga Nasional (The National Energy University), \\ Jalan IKRAM-UNITEN, 43000 Kajang, Selangor, Malaysia \\ ${ }^{2}$ Uniten Research and Development Centre \\ Universiti Tenaga Nasional (The National Energy University), \\ Jalan IKRAM-UNITEN, 43000 Kajang, Selangor, Malaysia \\ *Email: saifuddin@uniten.edu.my
}

\begin{abstract}
Biodiesel is receiving increasing attention as an alternative fuel due to the ever-growing demand for energy. However, the inferior physiochemical properties of biodiesel render it incompatible for gas turbine application, which needs to meet the standard requirement of gas turbine fuel accordance to ASTM D2880. In this quest, the biodiesel-dieselbioethanol blends might be a good option. In this paper, the research work was carried out to study experimentally the performance and exhaust emission characteristics of a $25 \mathrm{~kW}$ micro gas turbine engine (Capstone Model C30) fuelled with biodiesel-dieselbioethanol blends. The assessment on the improved fuel properties of biodiesel by blending with bio-ethanol had shown more superior atomisation characteristics performance compared to unmodified biodiesel. Moreover, the performance test in the micro gas turbine was limited up to $20 \%$ blend of biofuel, which showed improved thermal efficiency during the test. Subsequently, the emission test carried out in this work also showed significant enhancement in emissions, except nitrogen oxides $\left(\mathrm{NO}_{\mathrm{x}}\right)$ which contributed to the higher formation in comparison with the distillate diesel. Finally, B80E20 (80:20 of biodiesel-bioethanol) was proposed to be selected as an ideal blended fuel ratio to be applied in micro gas turbine engine due to its adaptability to replace diesel fuel, while showed better performance and emission properties as compared to the pure petroleum diesel.
\end{abstract}

Keywords: Gas turbine; biodiesel; bioethanol;, atomisation; Sauter mean diameter; engine performance; emissions

\section{INTRODUCTION}

Today, energy-intensive activities are the highest contributors to the increase in carbon dioxide $\left(\mathrm{CO}_{2}\right)$ emissions and fossil fuel combustion efficiency accounts for $90 \%$ of the total $\mathrm{CO}_{2}$ emissions [1-3]. Power generation remains the most important sector related to fossil fuel consumption. Therefore, the power sector choice of fossil fuel is of the utmost importance in reducing $\mathrm{CO}_{2}$ emissions [4]. The global average annual growth rate of 2.4 ppm in atmospheric $\mathrm{CO}_{2}$ concentrations in 2012 was rather high [5]. Renewable energy (RE) resources have become an increasingly significant part of power generation in the efforts to reduce fossil fuel consumption and pollutant emissions [6]. Among these, the 
two main types of liquid biofuels are bioethanol and biodiesel; both drawing considerable attention in the recent years [7]. Biodiesel is methyl ester of triglyceride prepared from edible or non-edible vegetable oils (virgin or used) or animal fats by the conversion of the triglycerides to esters via transesterification. The reproducibility, nontoxicity, and sulphur-free property of biodiesel have generated a lot of research interest. The primary focus has been on the use of biodiesel in diesel engines [1-3, 8-11]. The compatible physiochemical properties of biodiesel to diesel fuel have allowed up to $20 \%$ blending of biodiesel with petroleum diesel for the application in diesel engines without any modification [12-17].

Recently, there has been a lot of interest to consider biodiesel fuel for gas turbine application. Micro gas turbines (MGTs) are becoming more popular and experiencing greater demand due to their advantages of being small, modular, reliable. It is more flexible in terms of fuel, have compact size and light weight, are low in maintenance costs and emissions levels and high in efficiency, and lower electricity costs [18, 19]. Micro gas turbines are poised to take over from petrol and diesel reciprocating engines in a number of key applications due to their superior performance. Micro gas turbines are originally designed for the use of crude oil derivatives. However, it has been shown that biodiesel has shortcomings that need to be improved before it can be considered for gas turbine application. A study by Ivaniš, Radović [20] reported that biodiesel has higher density and viscosity than conventional diesel which results in poor atomisation of the fuels and may clog fuel nozzles. The properties of a liquid fuel that affect atomisation are viscosity, density, and surface tension. Atomisation refers to the process of breaking up bulk liquids into droplets. Atomisation plays a major role in the combustion efficiency and emission in gas turbines engines. Adequate atomisation enhances mixing and completes the combustion efficiency in a direct injection gas turbine. Higher density causes the fluid to resist acceleration and tends to result in a larger average droplet size. An increase in fuel density will also increase the surface tension of the fuel. Surface tension tends to stabilise the fluid and prevents its breakup into smaller droplets; hence, adversely affects the atomisation of the liquid. Viscosity causes the fluid to resist agitation, prevents its breakup and leads to a larger average droplet size. The use of a fuel with higher viscosity delays atomisation by suppressing the factors required to make the fuel spray to break up. Extensive research by Gao, Deng [21] on the spray characteristics of biodiesel found that the Sauter mean diameter (SMD) of biodiesel-blended fuels is larger than that of fossil diesel because of the higher viscosity and surface tension of biodiesel. Evaporation and atomisation of the biodiesel are relatively more difficult because of the higher surface tension and viscosity of the biodiesel.

Several techniques are available in order to modify the physical properties of the biofuel [22]. The properties of the fuels require modification according to the demands of the equipment. Several studies tried to use preheating in order to reduce the viscosity of the biodiesel [9, 23-29]. Some researchers showed that distillation process can be applied to improve the physical properties that affect atomisation characteristics of biodiesel for gas turbine application such as viscosity, density, and surface tension [30]. However, these processes are energy intensive and time consuming; hence, finding a non-laborious process (such as blending with bioethanol) is highly recommended. The outcome of the work by Yilmaz and Sanchez [31] implied that biodiesel-bioethanol blends are more effective than biodiesel-methanol blends in improving engine performance and emission. The addition of less viscous fuels with smaller surface tension into biodiesel is potentially capable of recovering the deteriorated spray characteristics compared to diesel. Similarly, Yoon, Park [32] showed that adding up to $20 \%$ (by volume) of bioethanol into biodiesel 
(BE20) enhances the spray characteristics of fuel blends. Studies showed that blending lower alcohols such as methanol and bioethanol with biodiesel only in lower proportions improves the engine performance. This is because of their lower heating value and higher latent heat of vaporisation $[33,34]$.

Accordingly, limited numbers of studies have focused on the application of bioethanol-biodiesel blends for the gas turbine engine. Similarly, there is a scarcity of published works on data examining combustion efficiency and emission of biodiesel blended with bioethanol, in particular, bioethanol produced from waste glycerol (a byproduct of biodiesel transesterification process). The notion that there is an enhancement of the combustion efficiency of biodiesel fuel when added with oxygenated fuels such as bioethanol needs a further study. Such investigation is important to understand which kind of blends is more effective in reducing both $\mathrm{NO}_{\mathrm{x}}$ and particulate emissions of a gas turbine engine. Hence, in evaluating the potential of bioethanol blended with biodiesel as an alternative fuel for gas turbines, it is a priority to ensure that the properties of the fuels are compatible with the gas turbine fuel properties so as not to violate the warranty of the equipment. Thus, the aim of the study is to investigate the performance and emissions of a gas turbine engine operating on bioethanol-Diesel-biodiesel blends, using biodiesel produced from palm oil and bioethanol produced from waste glycerol.

\section{METHODS AND MATERIALS}

\section{Blend Fuel Preparation and Property Test Evaluation}

The biodiesel obtained in this study was produced by utilising palm oil as the feedstock (via the alkali catalyst mediated trans-esterification process), which was obtained from the Sime Darby Biodiesel plant (Klang, Malaysia). Hence, the bioethanol used was produced from waste glycerol, as described elsewhere by Saifuddin and Refal [35]. Prior to its use in the experiments, the bioethanol used was dehydrated, which had undergone the prior water removal step as performed by following the method of Tomanee [36] without any modification. Distillate diesel as the baseline fuel was obtained locally (Petronas Gas Station, Malaysia). There were seven types of fuel used in the study for preliminary atomisation which included pure bioethanol (E100), pure biodiesel (B100), B20E80 ( biodiesel $20 \%$ blend with $80 \%$ bioethanol), B40E60 (biodiesel $40 \%$ blend with $60 \%$ bioethanol), B60E40 ( biodiesel $60 \%$ blend with $40 \%$ bioethanol), B80E20 (biodiesel $80 \%$ blend with $20 \%$ bioethanol), and distillate diesel (DD). However, there were also three types of fuel used for the performance and emission tests for micro gas turbine, namely, (i) 90\% Diesel: 9.0\% Biodiesel: 1.0\% Bioethanol (DBE10\%), (ii) $85 \%$ Diesel: 12.75\% Biodiesel: $2.25 \%$ Bioethanol (DBE15\%) and (iii) 80\% Diesel: 16\% Biodiesel: 4\% Bioethanol (DBE20\%). In this paper, all performance and emissions tests were performed at five engine loads, namely $5,10,15,20$, and $25 \mathrm{KW}$. All the fuel preparations were subjected to the property test evaluation in accordance with ASTM D2880 Standard Specification fuel oil requirements for gas turbine application, which were performed by third-party laboratories, namely, the TNB Research Laboratory and ITS Testing Services (M) SDN BHD.

\section{Numerical Evaluation of Preliminary Atomisation Characteristics}

The atomisation characteristics of blended biodiesel with various ratios of bioethanol were measured by determining the SMD parameter. SMD is designated as $\mathrm{D}_{32}$ and a very common parameter in fluid dynamics used for expressing the fineness of a spray in terms of the surface area, viscosity, and density of the spray droplets. The atomisation 
characteristic analysis was done numerically using Equation (1) reported by Lefebvre and McDonell [37].

$$
\frac{\mathrm{D}_{32}}{\mathrm{~d}_{0}}=0.48\left(\frac{\sigma}{\rho_{\mathrm{A}} \mathrm{U}_{\mathrm{R}}^{2} \mathrm{~d}_{0}}\right)^{0.4}\left(1+\frac{1}{\mathrm{ALR}}\right)^{0.4}+0.15\left(\frac{\mu_{L}^{2}}{\sigma \rho_{L} \mathrm{~d}_{0}}\right)^{0.5}\left(1+\frac{1}{A L R}\right)
$$

where $D_{32}=$ Sauter Mean Diameter; $d_{0}=$ Liquid discharge opening diameter $(\mathrm{m}) ; \sigma=$ Liquid surface tension $(\mathrm{N} / \mathrm{m}) ; \rho_{A}=$ Density of air $\left(\mathrm{Kg} / \mathrm{m}^{3}\right) ; U_{R}=$ Relative co flowing velocity of the two streams $(\mathrm{m} / \mathrm{s}) ; \rho_{L}=$ Density of liquid $\left(\mathrm{kg} / \mathrm{m}^{3}\right) ; \mu_{L}=$ Liquid viscosity $(\mathrm{kg} / \mathrm{ms})$; and ALR $=$ Air to liquid mass flow ratio.

Droplet evaporation time is another crucial element in atomisation and depends on the droplet size of the fuel. The fuel droplet size after atomisation depends on fuel delivery geometry and the properties of the fuel such as density, viscosity, and surface tension, while the evaporation rate depends on the specific heat, temperature at the evaporation zone and chemical structure of the-fuel molecules. Bolszo [38] analysed the evaporation time of diesel fuel in micro gas turbines using effective evaporation constant and droplet evaporation lifetime. Thus, a similar approach was used to evaluate the evaporation time of bioethanol and biodiesel. The details of Equations (2) to (4) are given for effective evaporation constant $\left(\lambda_{e f f}\right)$ calculated based on Bolszo [38].

$$
t_{e}=\frac{D_{32}^{2}}{\lambda_{\text {eff }}}
$$

where $\quad t_{e}=$ Effective evaporation time $\quad(\mathrm{s}) ; D_{32}=$ Sauter mean diameter ; $\lambda_{\text {eff }}=$ Effective evaporation constant $\left(\mathrm{m}^{2} / \mathrm{s}\right)$.

Since

$$
B=\left(\frac{1}{L}\right)\left\lceilC p \left(\mathrm{T}_{\infty}-\mathrm{T}_{l}+\left(\mathcal{Q} \frac{Y_{0 \infty}}{i}\right\rceil\right.\right.
$$

where $L=$ Latent heat of vaporisation per unit mass of fuel $(\mathrm{kJ} / \mathrm{kg}) ; T_{\infty}=$ Temperature of compressed air after recuperating $\left({ }^{\circ} \mathrm{C}\right) ; T_{l}=$ Surface temperature of fuel droplet $\left({ }^{\circ} \mathrm{C}\right) ; Y_{0 \infty}$ $=$ Mass fraction of oxidant in surrounding; $Q=$ Heat of reaction $\left({ }^{\circ} \mathrm{C}\right) ; i=$ Stoichiometric mixture ratio; $C p=$ Specific heat of liquid fuel droplet $(\mathrm{kJ} / \mathrm{kg} . \mathrm{K})$,

and

$$
\lambda_{\mathrm{eff}}=\frac{8 \kappa}{\rho_{\mathrm{\iota}} \mathrm{Cp}} \ln (1+\mathrm{B})
$$

Where $\quad \kappa=$ Thermal conductivity of gas around the droplet $\quad(\mathrm{W} / \mathrm{m} . \mathrm{K}) ; \quad \rho_{\iota}=$ Fuel density $\left(\mathrm{Kg} / \mathrm{m}^{3}\right) ; C p=$ Specific heat of gas around the deplete $(\mathrm{kJ} / \mathrm{kg} . \mathrm{K}) ; B=$ Heat transfer number.

\section{Performance and Emission Tests for Micro Gas Turbine}

The performance test of biofuel blend with distillate diesel was conducted in a liquid fuelled micro turbine (Capstone Model C30) at UNITEN Gas Turbine laboratory. A schematic plant-layout of the micro gas turbine engine and accessories are shown in Figure 1. The micro turbine generator performance test for this study was measured by thermal efficiency and specific fuel consumption. The performance test was conducted at 
ambient temperatures of $23.9{ }^{\circ} \mathrm{C}$ to $24.2{ }^{\circ} \mathrm{C}$, achieved by using the cooling equipment. This is because the power output is affected by ambient temperature; hence, conducting the test at the lowest ambient temperatures is recommended to achieve the highest power output. The micro turbine was calibrated in accordance with the manufacturer correction curves during commissioning prior to the testing. The micro turbine was started and run for 30 min using diesel to warm up the equipment before switching to the designated test fuel when the micro turbine has reached the steady-state condition. This steady-state condition was achieved when the temperatures of the exhaust gases, mass flow rate, and electric power output reached a stable reading. Then, the power output was varied from idle to $25 \mathrm{~kW}$ with intervals of $5 \mathrm{~kW}$, whilst ensuring that steady state conditions were reached before measurements were recorded.

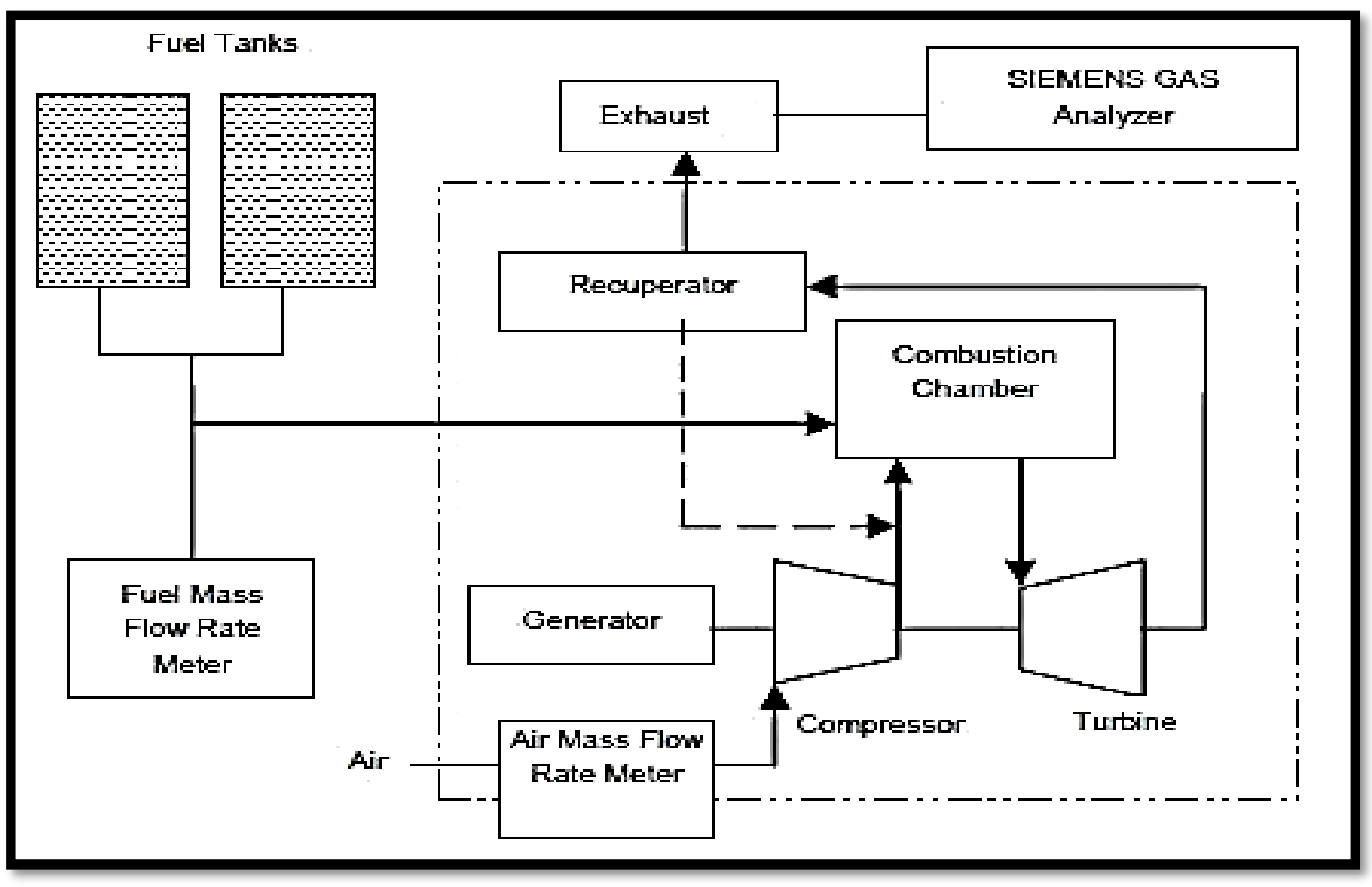

Figure 1. A schematic plant-layout of the micro gas turbine engine.

Meanwhile, the test fuels were also evaluated accordingly with a continuous emission monitoring system (CEMS) to evaluate the emissions of the micro turbine. CEMS was used at a sample port on the exhaust stack of the micro turbine for emission monitoring. The data for emission exhaust gases such as carbon $\mathrm{CO}, \mathrm{CO}_{2}, \mathrm{O}_{2}$, and $\mathrm{NO}_{\mathrm{X}}$ were recorded at $5 \mathrm{~s}$ intervals. Prior to use, the instrument analyser was calibrated periodically with an available sample with known quantities of gas. The entire performance test was conducted in accordance with calculations of Standard [39]. The following equations were used for the calculation of thermal efficiency and brake-specific fuel consumption respectively. Thermal efficiency was derived from the formula shown in Equations (5) to (8).

$$
\eta=\frac{\mathrm{W}_{\text {net }}}{\mathrm{HI}}
$$

where $W_{\text {net }}=$ Generator power obtained from the data acquisition system $(\mathrm{KW}) ; H I=$ Heat input (KW). Meanwhile, heat input was derived from Equation (6). 


$$
\mathrm{HI}=\mathcal{Q}_{\mathfrak{\iota}} \rho_{\mathfrak{\iota}}\left(\mathrm{LHV}_{\mathfrak{p}}\right)+\mathrm{SH}_{\mathfrak{p}}
$$

where $\mathcal{Q}_{\mathrm{L}}=$ Volumetric flow (Litre/sec); $\rho_{\iota}=$ Density of the liquid fuel at operating temperature $\left(\mathrm{kg} / \mathrm{m}^{3}\right) ; L H V_{\mathfrak{p}}=$ Lower heating value at constant pressure $(\mathrm{kJ} / \mathrm{kg})$; $S H_{\mathfrak{p}}=$ Sensible heat at constant pressure $(\mathrm{kJ} / \mathrm{sec})$.

From Equation (7), the lower heating value can be obtained. The higher heating value can be calculated from equation (8):

$$
\mathrm{LHV}_{\mathfrak{p}}=\mathrm{HHV}_{\mathcal{V}}-91.20(\mathrm{H})
$$

where $H H V_{v}=$ Higher heating value at constant volume in accordance with ASTM D4809 $(\mathrm{kJ} / \mathrm{kg}) ; H=$ Percentage of hydrogen by weight contained in the liquid fuel and determined in accordance with ASTM D1018.

$$
\mathrm{SH}_{\mathfrak{p}}=\mathcal{Q}_{\mathrm{\iota}} \rho_{\mathrm{\iota}}-\left(\mathrm{h}_{\mathrm{l}}-\mathrm{h}_{\mathrm{l}, 77}\right)
$$

where $h_{l}=$ Specific enthalpy of the liquid fuel at operating temperature of $27.38^{\circ} \mathrm{C}$ $(\mathrm{kJ} / \mathrm{kg}) ; h_{l, 77}=$ Specific enthalpy of the liquid fuel at a standard operating temperature of $25^{\circ} \mathrm{C}(\mathrm{kJ} / \mathrm{kg})$.

The brake-specific fuel consumption (BSFC) from the micro turbine system was derived from Equation (9).

$$
\mathrm{BSFC}=\frac{\text { Average Mass Flow Rate of Fuel }}{\text { Average Load }}
$$

\section{RESULTS AND DISCUSSION}

\section{Sauter Mean Diameter Analysis of Bioethanol Blends with Biodiesel}

The major goal of atomisation is to increase the surface to volume ratio to enhance liquid evaporation and combustion efficiency. The biggest requisite for atomisation is that a relative velocity between the liquid to be atomised and surrounding air is high. One way to obtain this is by inserting moving liquid on a high-velocity airstream. Among the many methods of atomisation, the micro turbine deploys air blast atomising for its fuel combustion system as the air used to atomise the liquid promotes a good blend and better atomisation. SMD is the most widely used parameter to define the droplet size in a spray. Due to cost constraints, an SMD formula generated from Lefebvre correlation was adopted to numerically evaluate the SMD of bioethanol and its blends with biodiesel fuel, as a similar correlation was previously used to evaluate SMD of diesel fuel in Capstone C30 micro gas turbine with air blast atomiser, which has been experimentally validated using the phase doppler anemometer (PDA), air to liquid ratio (ALR), and relative coflowing velocity exiting (UR) value adopted from a report by Bolszo [38].

Based on Figure 2, using Lefebvre equation, the patterns of all fuels were identical where SMD decreased gradually as the atomisation air to liquid mass flow ratio ALR spanned from 0.2 to 0.65 . In a prompt atomisation process, air velocity, ALR, and fuel properties such as surface tension and density play primary roles, while viscosity takes a reduced role [40]. In general, test fuels have smaller droplet size at a high air velocity injection. At the low values of ALR, the kinetic energy of the atomising air was insufficient to overcome the viscous and surface tension forces which opposed the disintegration of the liquid. As ALR increased, it was evident that not only the droplets 
were quite smaller but also the difference between the largest and smallest droplets decreased significantly. In fact, for the highest values of ALR shown in Figure 2, there was a difference between the droplet sizes of the entire fuels. However, as can be anticipated, the highest atomising air velocities result in the finest atomisation. The biodiesel had a higher SMD value for all cases, though at the highest velocities produced an average SMD larger than the other fuels. Yoon, Park [32] in their investigation revealed that the measured results of biodiesel-bioethanol blended fuel showed SMD decreased with the increase of the relative velocity between the injected fuel and ambient gas. In conclusion to their work, the atomisation performance of test fuels was remarkably affected by the difference of relative velocity. Therefore, BE10 and BE20 have a smaller SMD distribution compared with ultra-low sulphur diesel (ULSD). The SMDs calculated using Lefebvre equation for all sample fuels prepared is illustrated in Figure 2. The results exhibited in Table 1 show that bioethanol has the lowest surface tension, density, and viscosity compared to biodiesel and distillate diesel, while the most significant reduction was found for viscosity.

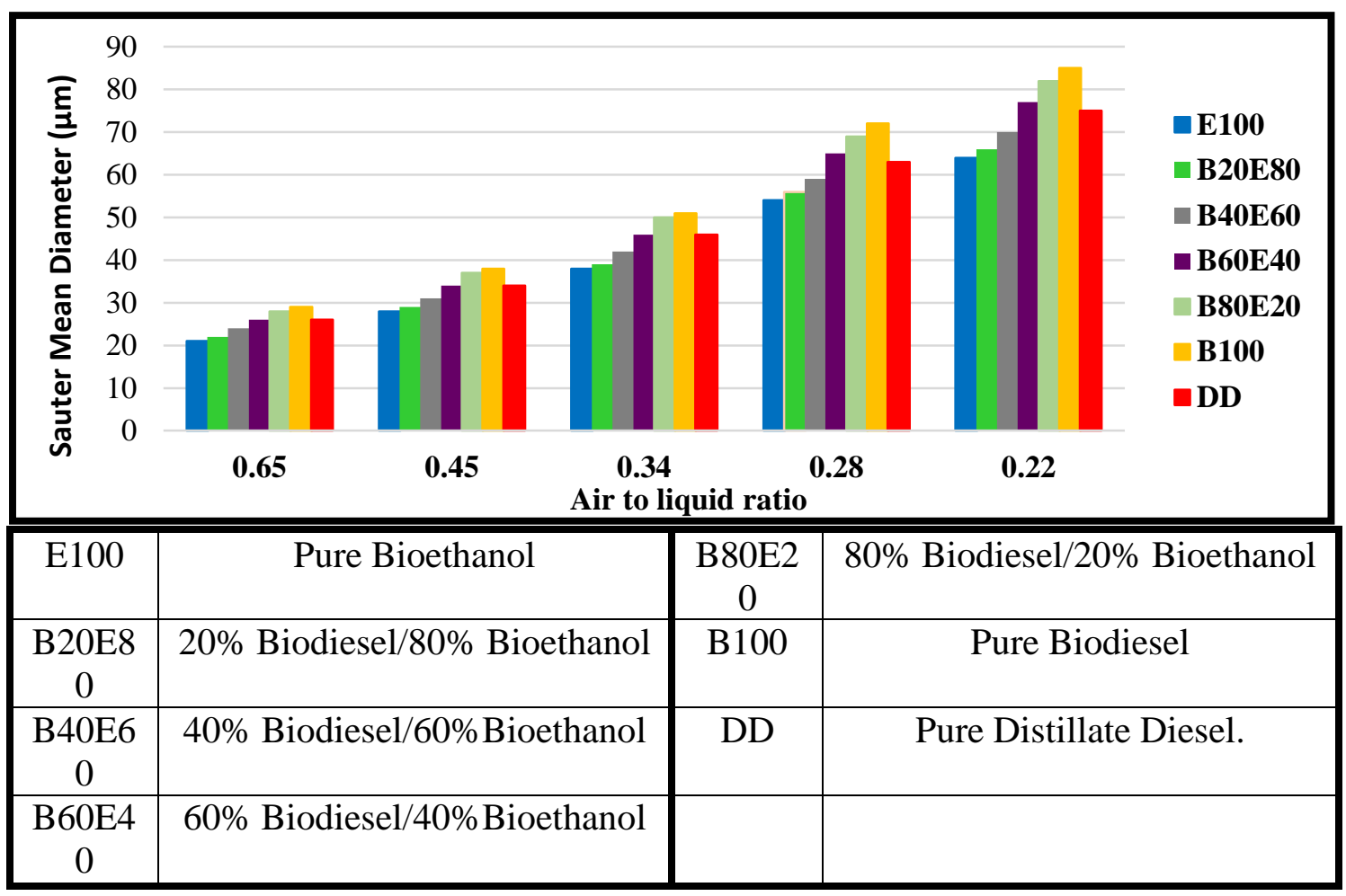

Figure 2. Effect of air to liquid ratio on SMD using different blends of fuel (bioethanol and distillate diesel)

Pure biodiesel fuel (B100) has the largest SMD, followed by B80E20, B60E40, DD, B40E60, B20E80, and pure bioethanol. SMD of biodiesel blends was much larger when compared to diesel because of the higher value of viscosity and surface tension of biodiesel [41]. When bioethanol was added, the blended fuels gave smaller droplets and when the blending ratio of bioethanol increased, the diameter became even smaller. This is because the addition of bioethanol led to a more active breakup process. This indicates that the addition of bioethanol reduces the droplet size and enhances the mixture formation. The higher viscosity and larger surface tension of biodiesel inhibited its atomisation process, and as bioethanol increased, the viscosity and surface tension of the 
blended fuel decreased (Table 1). Referring to Table 1, the higher ratio of bioethanol in a fuel will correspond to the lower density, viscosity, and surface tension. This will favour the break of droplets due to the reduced resistance to shear stress and thus, better atomisation performance was achieved.

Table 1 Physical property of test fuel used for atomisation assessment

\begin{tabular}{cccc}
\hline Fuel Samples & $\begin{array}{c}\text { Density } \\
\left(\mathrm{kg} / \mathrm{m}^{3}\right)\end{array}$ & $\begin{array}{c}\text { Viscosity } \\
\left(\mathrm{mm}^{2} / \mathrm{s}\right)\end{array}$ & $\begin{array}{c}\text { Surface Tension } \\
(\mathrm{mN} / \mathrm{m})\end{array}$ \\
\hline E100 & 811.0 & 1.19 & 22.30 \\
B80E20 & 860.0 & 4.26 & 31.32 \\
B60E40 & 854.0 & 3.37 & 28.88 \\
B40E60 & 845.0 & 2.18 & 25.93 \\
B20E80 & 837.0 & 1.36 & 24.11 \\
DD & 845.0 & 3.95 & 23.00 \\
B100 & 874.0 & 4.60 & 34.00 \\
\hline
\end{tabular}

It is interesting to note that distillate diesel (DD) and blended 60BE40 fuel had a similar tendency of droplet size over the entire range of measurement. This was consistent with the study by Guan, Tang [42] who characterised the diameter size of biodiesel (B100) and diesel by the particle/droplet image analysis (PDIA) technique. They examined that the diameters for the fuels were $25 \mu \mathrm{m}$ and $20 \mu \mathrm{m}$. However, when di-nbutyl ether (DBE) was blended into biodiesel with a volume fraction of $15 \%$ and $30 \%$, the diameters decreased to $21 \mu \mathrm{m}$ and $16 \mu \mathrm{m}$, respectively. Likewise, Yoon et al. [18] concluded that by adding up to $20 \%$ (by volume) of bioethanol into biodiesel (BE20), the droplet size of BE10 and BE20 was smaller than of diesel. The smaller the size of fuel drops in the air-fuel mixture, the faster the air-fuel mixture evaporates in the cylinder and the higher the combustion velocity of the air-fuel mixture [43]. This affirms that the improvement in physical properties by blending with different biofuels which are less viscous can reduce SMD of different percentage ratios of biodiesel compared with pure biodiesel and lead to better combustion efficiencies.

\section{Droplet Evaporation Time (DET) of Bioethanol and Biodiesel}

DET is another crucial element that influences the combustion efficiency and its dependence on the droplet size of the fuel. Decreasing the size of the fuel drops decreases evaporation time of the air-fuel mixture and therefore, will increase the combustion velocity of the air-fuel mixture [44]. The evaporation time of droplets was analysed using effective evaporation time constant and the droplet lifetime was determined using the $\mathrm{D}^{2}$ law. According to the experimental data by Bolszo [38], when using ideal premixing and pre-vaporization at $30 \mathrm{~kW}$ load, the Capstone $\mathrm{C} 30$ required 11 milliseconds (ms) for the droplets with SMD $50 \mu \mathrm{m}$ of diesel to be fully vaporized corresponding to the value $(0.28)$ of ALR. Hence, in order to determine the evaporation time of neat bioethanol and biodiesel, experimental data from Bolszo's work were adapted for this analysis to estimate the required evaporation time for the droplets (to be fully vaporized) in the micro turbine. Table 2 shows DET of bioethanol, biodiesel, and distillate diesel, respectively. It was observed that at lower ALR, (same operation condition as Bolszo's work), the biodiesel and diesel required 21 and $18 \mathrm{~ms}$, respectively to be fully vaporized, whereas bioethanol required $23 \mathrm{~ms}$ for a $54 \mu \mathrm{m}$ droplets, which require a much longer time to evaporate. 
Chong and Hochgreb [45] reported that fuel droplets with higher SMD contain high momentum and thus have extended evaporation time. However, the results of this research showed that decreasing the size of the bioethanol drops increased the evaporation time of the air-fuel mixture. This is in contrast for the liquid fuel like biodiesel and diesel; although their droplet size was bigger, the evaporation time was lower compared with bioethanol. This phenomenon is due to the very high evaporation enthalpy of bioethanol, causing the droplets evaporation rate to be limited. Thus, bioethanol behaved much more like a high boiling point fuel compared to biodiesel and diesel. As can be seen from Table 3 , the latent heat of vaporization of bioethanol $(840 \mathrm{~kJ} / \mathrm{kg})$ was the highest, which was three times higher than that of biodiesel and diesel (230 and $250 \mathrm{~kJ} / \mathrm{kg}$, respectively). Consequently, more heat energy is required to evaporate a sufficient amount of fuel to make a combustible fuel to air mixture. This issue is more severe for bioethanol as compared to biodiesel and diesel due to its higher vaporization energy.

Table 2. DET of bioethanol, biodiesel and distillate diesel.

\begin{tabular}{|c|c|c|c|c|c|c|}
\hline \multirow{2}{*}{ ALR } & \multicolumn{4}{|c|}{$\begin{array}{l}\text { Distillate Diesel } \\
\text { (D100) }\end{array}$} & \multicolumn{2}{|c|}{ Biodiesel (B100) } \\
\hline & $\mathrm{SMD}(\mu \mathrm{m})$ & DET (ms) & $\begin{array}{l}\text { SMD } \\
(\mu \mathrm{m})\end{array}$ & DET (ms) & $\begin{array}{l}\text { SMD } \\
(\mu \mathrm{m})\end{array}$ & DET (ms) \\
\hline 0.65 & 21 & 4 & 26 & 3 & 29 & 4 \\
\hline 0.45 & 28 & 6 & 34 & 5 & 38 & 6 \\
\hline 0.34 & 38 & 11 & 46 & 9 & 51 & 11 \\
\hline 0.28 & 54 & 23 & 63 & 18 & 72 & 21 \\
\hline 0.22 & 64 & 33 & 75 & 25 & 85 & 29 \\
\hline
\end{tabular}

Table 3. Physical properties of fuels that affect the rate of evaporation time.

\begin{tabular}{ccc}
\hline Fuels & $\begin{array}{c}\text { Latent Heat of Evaporation } \\
(\mathrm{kJ} / \mathrm{kg})\end{array}$ & $\begin{array}{c}\text { Specific Heat of Fuel Droplet } \\
(\mathrm{kJ} / \mathrm{kg} . \mathrm{K})\end{array}$ \\
\hline E100 & 840 & 2.55 \\
DD & 250 & 1.85 \\
B100 & 230 & 1.90 \\
\hline
\end{tabular}

The experiment results obtained in this study were supported by the work of Benjumea, Agudelo [46], who stated that the lower heat of vaporisation of palm methyl ester of approximately 200 220 kJ/kg had faster evaporation compared to diesel which had $375 \mathrm{~kJ} / \mathrm{kg}$ latent heat of vaporisation at the same operating condition. Similarly, Zhang, Xu [47] reported that the evaporation of methanol and bioethanol fuels was much slower than that of gasoline because of their lower vapour pressures and higher latent heats of vaporization. Bagul AD [48] stated that the vaporization of bioethanol blends requires more heat input than needed to vaporize the same mass of gasoline. The lower vapour pressures and higher latent heats of vaporization are still the challenges for the evaporation of alcohol fuels because inadequate vaporization of the fuel can lead to an increase in hydrocarbon emissions. Iranmanesh [49] reported that the higher heat of evaporation of the bioethanol or diethyl ether in the fuel blends tends to produce slow vaporization and poorer fuel-air mixing which subsequently produces incomplete combustion efficiency of the mixture. 
Specific heat capacity is another critical factor that influences the evaporation rate. Bioethanol has a higher specific heat than biodiesel and diesel, which means that it requires higher energy to raise the temperature of the liquid fuel. The results from this work is in a good agreement with $[50,51]$ where they reported that the specific heat of the bioethanol fuel is higher than that of pure gasoline and this leads to the decrease in the drop of the charge temperature. Hence, more addition of bioethanol decreases combustion temperature (caused by its increased specific heat) in contrast with biodiesel and diesel. It can be concluded by using direct proportional assumption (as shown in Table 3) that the increase in bioethanol percentage ratio in blended fuel could lead to prolonged ignition delay period and reduced combustion flame temperature. This is explained as mentioned earlier by the higher latent heat of vaporization and specific heat value of bioethanol, which are considered as the most influential factors [52]. Based on the results, it is recommended that the micro gas turbine operation is limited to up to $20 \%$ blend of bioethanol so as to achieve a balance of good droplet size and combustion efficiency characteristics.

\section{Micro Gas Turbine Engine Performance Characteristics Evaluation}

The analyses of performance and emissions characteristic of micro gas turbine fuelled with biofuel (Biodiesel-Bioethanol) blended with distillate diesel and using load ranging from $5 \mathrm{~kW}$ to $25 \mathrm{~kW}$ were carried out. The comparative parameter to determine the efficiency of conversion of fuel into work to power the micro gas turbine was measured by brake specific fuel consumption (BSFC). Fuel consumption is a measure of the volumetric fuel consumption for any particular fuel and depends on a number of parameters, namely the calorific value. In general, the brake thermal efficiency is simply the inverse of the product of fuel consumption and the lower calorific value of the fuel. Figure 3 indicates the variations of the BSFC for different diesel-biodiesel-bioethanol blended fuels ratio under various engine loads. The brake specific fuel consumption trends for diesel and the blends are similar in nature. The results showed that increasing bioethanol proportion in the fuel blend increased the BSFC. This behaviour is attributed to the heating value per unit mass of the bioethanol $(31825 \mathrm{~kJ} / \mathrm{kg})$, which was noticeably lower than that of the diesel and biodiesel fuels $(45088,40023 \mathrm{~kJ} / \mathrm{kg}$, respectively). Yilmaz [53] studied the performance and emission of biodiesel-diesel-ethanol blends (B45E10D45, B40E20D40) in a diesel engine at different load conditions. They found that the use of ethanol in the biodiesel-diesel blend showed higher fuel consumption than that of diesel fuel. From Figure 3, it can be seen that BSFC for the blend fuel DBE10 was the most comparable ratio to neat diesel (DD) for all loads tested. This is because of the high heating value of the blend in comparison to the BSFC of DBE15 and DBE20. These results agree with those found by other authors $[54,55]$.

The brake specific fuel consumption is greater at smaller loads, but it decreases at medium and higher loads. For the same loads, the bioethanol blends exhibited higher consumption due to lower heating values (meaning less energy content than pure diesel fuels). Different properties of the test fuels significantly affected the brake thermal efficiency of the engine. The higher thermal efficiency in turn helped to achieve better combustion efficiency and lower emissions correspondingly. The variation of brake thermal efficiency for pure diesel and its blends of up to $20 \%$ of biodiesel-bioethanol for the low and high loads are shown in Figure 4. The brake thermal efficiency for the $20 \%$ ratio (80:16:4 of diesel-biodiesel-bioethanol) fuel was found to be $21.92 \%$ (at test load of $20 \mathrm{~kW}$ ); which was very close to the value of pure diesel $(22.87 \%)$ at a similar load. It should be noted that an increase in the thermal efficiency was observed in spite of the fact 
that the calorific values of the blends were lesser than the values for pure diesel. The increase in the thermal efficiency can be attributed to the addition of the oxygenated additive, which decreased the viscosity of the mixture, improved the atomisation and fuel vaporization and thereby enhanced the combustion efficiency of the fuel to a greater extent. Besides that, the thermal efficiency of blends was also improved due to faster burning of bioethanol in the blend (An increase in the rate of heat release due to rapid combustion of bioethanol by flame propagation). These results agreed with those found by other authors $[56,57]$.

\begin{tabular}{|c|c|c|c|c|}
\hline & & & \\
\hline
\end{tabular}

Figure 3. Brake specific fuel consumption at various load using different fuels blends

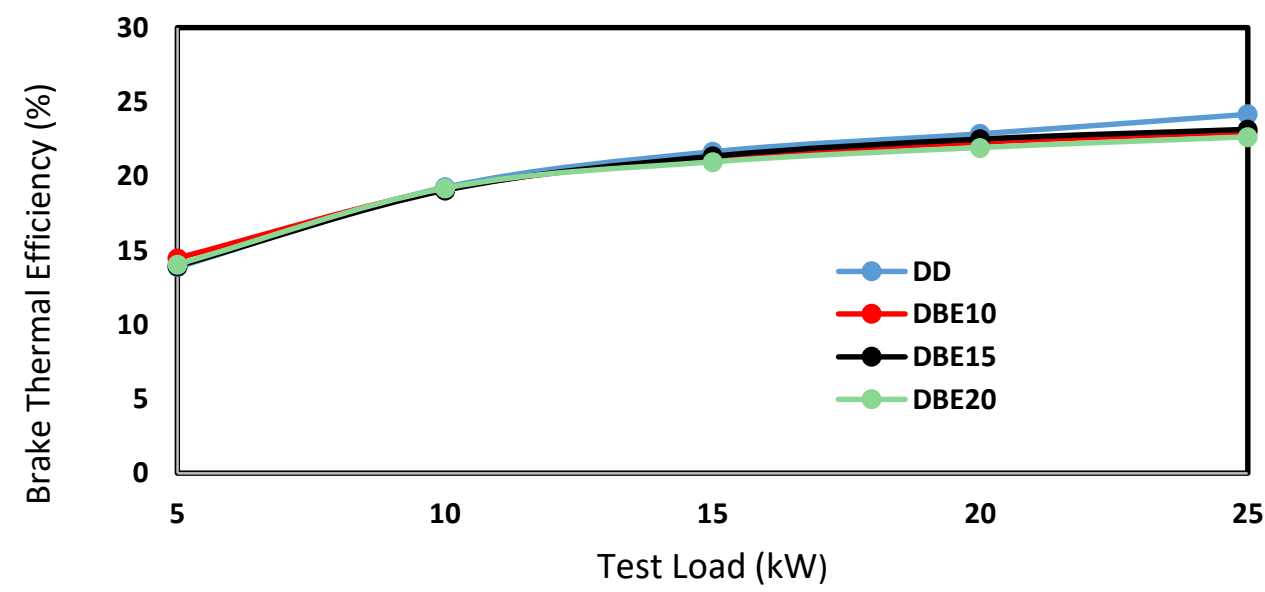

Figure 4. Variation of brake thermal efficiency of the micro gas turbine at different loads using various fuel blends. 
At the maximum test load of $25 \mathrm{~kW}$, it was observed that the thermal efficiency of the blend was marginally lower than diesel. Thermal efficiency was $22.99 \%, 23.16 \%$, and 22.64\% for DBE10 (90:9:1 of diesel-biodiesel-bioethanol), DBE15 (85:12.75: 2.25 of diesel-biodiesel-bioethanol), and DBE20 (80:16:4 of diesel-biodiesel-bioethanol), respectively. The slight variations in the thermal efficiency of the DBE blends were mainly due to the lower calorific value of bioethanol when compared to diesel and biodiesel. The results of this work concurred with Krishna, Bandewar [58] who found the brake thermal efficiency of the blend was $26.73 \%$ as compared to $23.21 \%$ of Karanja oil and $27.01 \%$ of pure diesel. Similar results were also reported by Anand R [59], who showed that at $100 \%$ load condition, the maximum brake thermal efficiency of biodieselbioethanol blends (B90E10) was higher than that of B80E20 and lower than that of diesel fuel. Thus, it can be concluded that most works have reported that the thermal efficiency of the fuel blends is marginally lower than diesel at the maximum engine power output.

\section{Exhaust Emission Comparison of Micro Gas Turbine Operating on Biofuel Blends with Distillate Diesel}

Renewable bio-fuels also emit pollutants that are equally detrimental to the environment and specifically dependant to the combustion dynamic of a particular engine. $\mathrm{CO}_{2}$ is one of the main combustion products which are very important in determining the completeness of a combustion reaction of the fuel. The variation of $\mathrm{CO}_{2}$ with various loads for diesel fuel and diesel-biodiesel-bioethanol blends is illustrated in Figure 5.

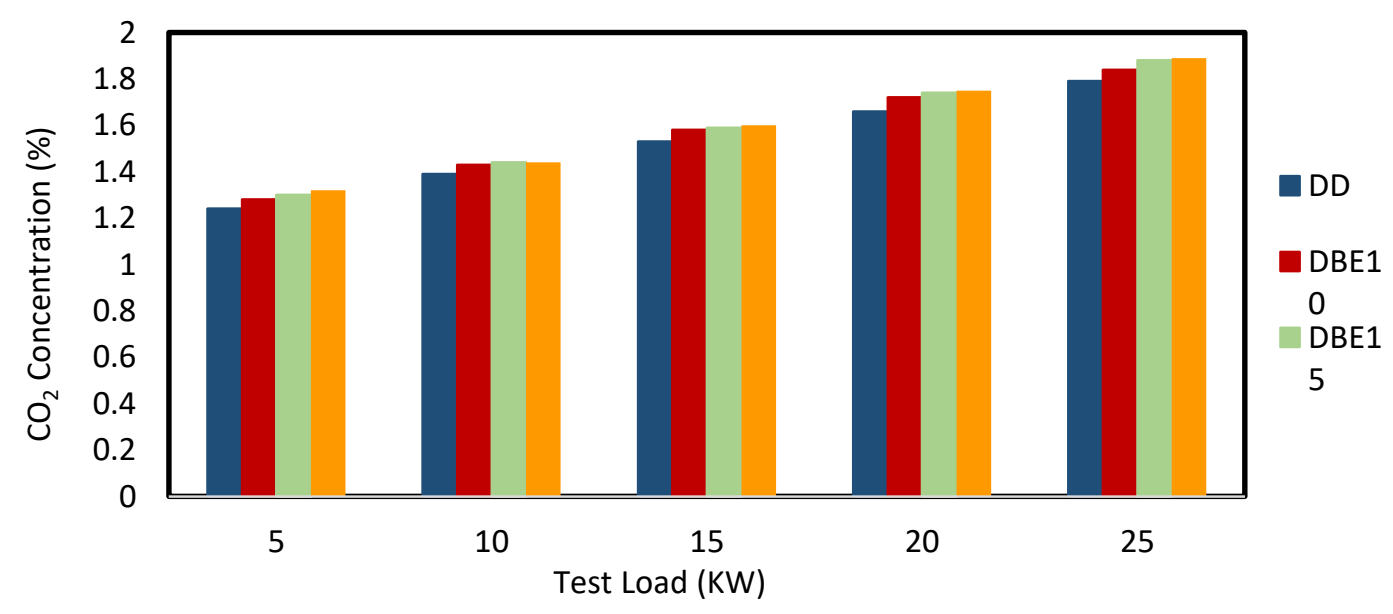

Figure 5. Variation of $\mathrm{CO}_{2}$ emissions from micro gas turbine at different test loads for different fuel blends

It was found that as the load increased, $\mathrm{CO}_{2}$ emissions increased as more and more fuel was burned at high load while complete combustion efficiency was achieved at the high loads due to high temperature. This trend was similar for all fuel blends. The $\mathrm{CO}_{2}$ emissions of DBE10, DBE15, and DBE20 (at the highest test load of $25 \mathrm{~kW}$ ) were higher $(1.84 \%, 1.88 \%$, and $1.89 \%$, respectively) than those of diesel fuel and increased with the increase of bioethanol percentage. This was due to the complete combustion efficiency caused by the presence of highly oxygenated bioethanol supply, thus the emission of $\mathrm{CO}_{2}$ increased with the increase in bioethanol percentage of blends. These results were in agreement with Cheenkachorn and Fungtammasan [60] and Subbaiah, Gopal [61] who showed that at the high engine speed and load, the $\mathrm{CO}_{2}$ emissions increased as more and more fuel burned more excess air. They also observed that the $\mathrm{CO}_{2}$ concentrations 
emissions from all biodiesel-bioethanol-diesel blend fuels were higher than that of diesel fuel. Deshpande SS [62] stated in their research that for the blended fuel of DBE10, the $\mathrm{CO}_{2}$ emissions were higher at all loads and maximum increase was $66.37 \%$ as compared to the pure diesel. However, they reported that for the blend DBE20, the $\mathrm{CO}_{2}$ emissions were lower at all loads in comparison with the fuel DBE10. Their result was in contrast with this study, which showed that DBE20 emitted more $\mathrm{CO}_{2}$ emissions for all test loads compared to DBE10, and DBE15.

Another important emission gas is carbon monoxide (CO). During the complete combustion efficiency, the conversion of $\mathrm{CO}$ into $\mathrm{CO}_{2}$ takes place whereas if the combustion efficiency is incomplete due to shortage of air or the low gas temperature, more $\mathrm{CO}$ will be formed. Formation of $\mathrm{CO}$ indicates loss of power, resulting in oxygen deficiency in the combustion chamber [63]. The variation of $\mathrm{CO}$ with loads for different fuels is shown in Figure 6.

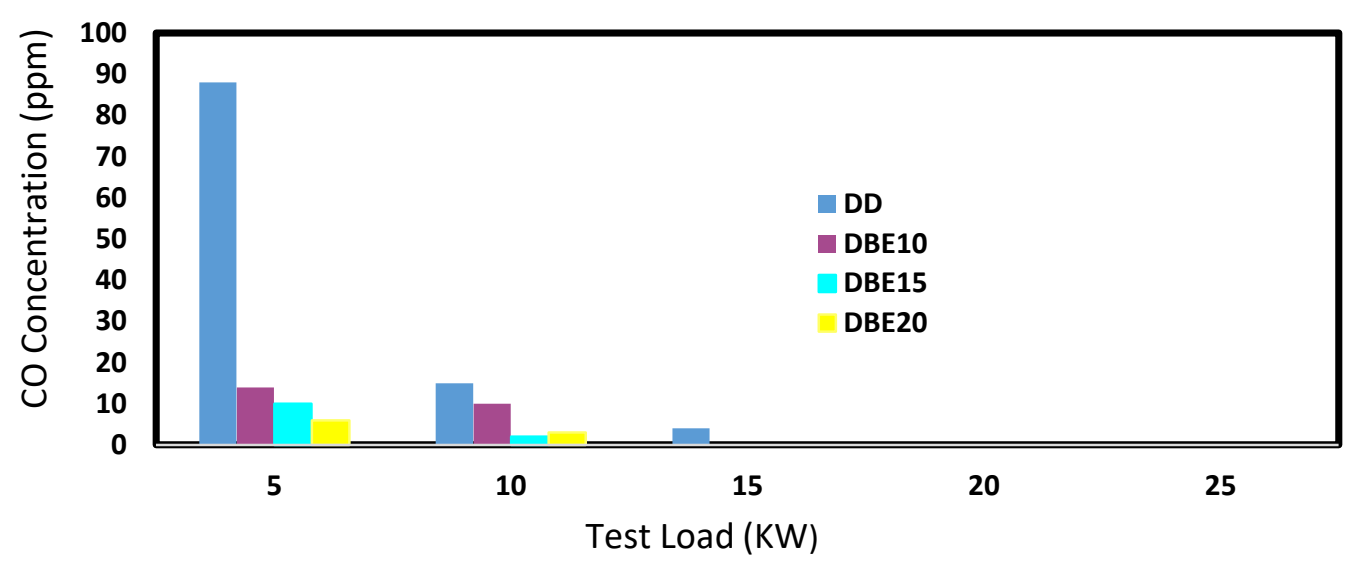

Figure 6 Variation of $\mathrm{CO}$ emissions from micro gas turbine at different test loads for different blended fuels.

Emissions of $\mathrm{CO}$ from engine mainly depend on the physical and chemical properties of the fuel. The $\mathrm{CO}$ emissions of the diesel-biodiesel-bioethanol blend fuels were much different from that of conventional diesel at the low loads as shown in Figure 6. However, the $\mathrm{CO}$ emissions slightly increased at the low loads and decreased significantly at the higher loads with all the fuel modes. The report by Hulwan and Joshi [54] indicated that CO emissions were drastically increased at the low loads using the high percentage of bioethanol in diesel-bioethanol blends. They reported that the drastic increase in the $\mathrm{CO}$ percentage at the low load for the blend was due to the decrease in the cylinder gas temperature and delayed combustion efficiency process, even though enough oxygen was available for the combustion efficiency process. The reduction in $\mathrm{CO}$ emissions was noticed for blends at the high load due to the high temperature and enrichment of oxygen owing to the bioethanol addition, in which an increase in the proportion of oxygen will promote further oxidation of $\mathrm{CO}$ during the engine exhaust process [59-64].

The experimental results of Barabas, Todorut [65] showed that at the high engine loads, the lowest CO emission ( $0.234 \%$ vol.) was for the biodiesel $10 \%$-diesel $85 \%$ ethanol 5\% (B10D85E5) mixture. This compared to the one seen in the diesel fuel case $(0.575 \%$ vol.) represented a $59 \%$ reduction. In the previous works by several researchers, it was suggested that the higher oxygen content of the blended fuels could improve the combustion efficiency process while the lower viscosity and density of the blended fuels 
could lead to better air-fuel mixing, which can sufficiently burn all fuel, resulting in the lower CO emissions [52, 66, 67].

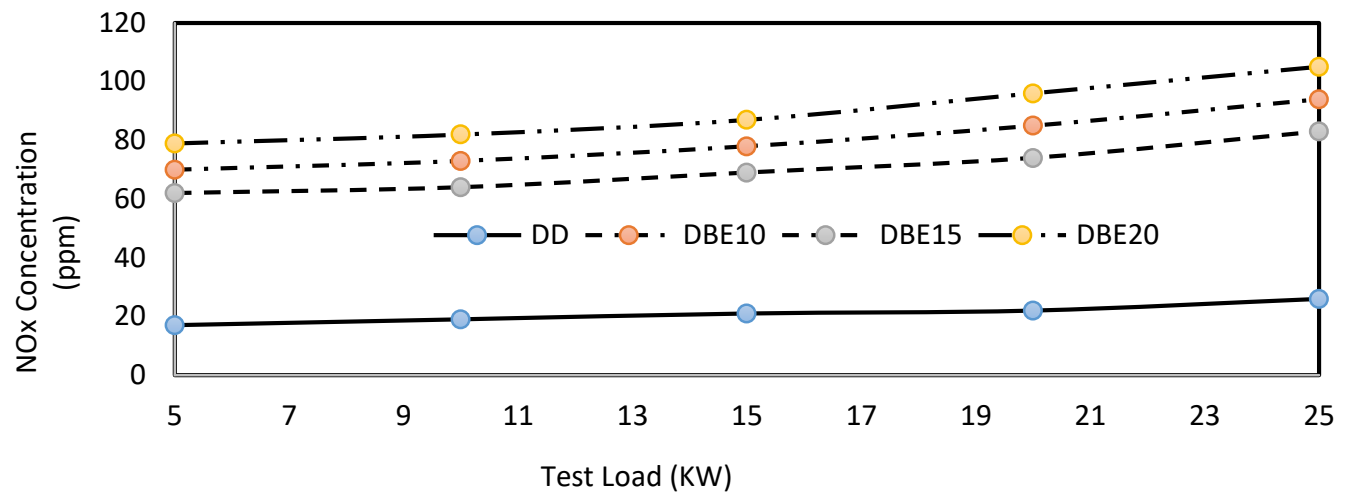

Figure 7. Variation of oxides nitrogen emissions from the micro gas turbine at different test loads for different blended fuels.

The most troublesome emissions from engines are $\mathrm{NO}_{\mathrm{x}}$. It is produced during the combustion efficiency process when nitrogen and oxygen are present at elevated temperatures. The oxides of nitrogen in the exhaust emissions contain nitric oxide (NO) and nitrogen dioxide $\left(\mathrm{NO}_{2}\right)$. The formation of $\mathrm{NO}_{\mathrm{x}}$ is highly dependent on the combustion temperatures, oxygen concentration, and residence time for the reaction to take place [68]. The variation of nitrogen oxides with loads for diesel fuel and diesel-biodiesel-bioethanol blends is presented in Figure 7. It can be observed that $\mathrm{NO}_{\mathrm{x}}$ emitted by all fuels blends are higher than the ones for the corresponding pure diesel fuel case. The $\mathrm{NO}_{\mathrm{x}}$ emissions of diesel-biodiesel-bioethanol blends were lower at the low loads and higher at medium and high loads than those of diesel fuel. This was due to the higher combustion temperature as well as the oxygen content of the bioethanol at medium and high loads versus the diesel fuel. The $\mathrm{NO}_{\mathrm{x}}$ emissions of DBE10, DBE15, and DBE20 were 94\%, $83 \%$, and $105 \%$ higher compared to those of the diesel at full load $(25 \mathrm{~kW})$ of the engine. Generally the higher oxygen content results in the higher combustion temperature which leads to the higher $\mathrm{NO}_{\mathrm{x}}$ emission. This result was comparable with Mofijur, Rasul [69] who also found less influence of oxygenated components of the fuel blends in the $\mathrm{NO}_{\mathrm{x}}$ formation at smaller loads. Nevertheless, at the medium and high engine load conditions, the $\mathrm{NO}_{\mathrm{x}}$ emission increased by 10-26\% compared to diesel fuel. Most of the studies on this fuel concluded that the higher oxygen content and low viscosity in bioethanol fuel can lead to better mixing, improve combustion efficiency and rise the combustion chamber temperature, which contributes to the higher formation of $\mathrm{NO}_{\mathrm{x}}$ emissions [54, 70]. Thus, with the increase of bioethanol in the blended fuel, $\mathrm{NO}_{2}$ emission increased correspondingly at the high load engine. Opposite results were also observed by several considerable studies that developed new methods for the reduction of $\mathrm{NO}_{\mathrm{x}}$ emission from the diesel engine by using selective catalytic reduction technology. An experiment research by Xiaoyan, Yunbo [70] used three types of catalyst for $\mathrm{NO}_{\mathrm{X}}$ emission reduction. They observed approximately a 5.5\% increase in $\mathrm{NO}_{\mathrm{x}}$ emission from the dieselbiodiesel-ethanol blend without any catalyst assembly. However, when they used the $\mathrm{Ag} / \mathrm{Al}_{2} \mathrm{O}_{3}$ catalyst, $\mathrm{NO}_{\mathrm{x}}$ was reduced by $73 \%$. Again, when the exhaust was passed through the $\mathrm{Ag} / \mathrm{Al}_{2} \mathrm{O}_{3}+\mathrm{Cu} / \mathrm{TiO}_{2}$ catalyst and $\mathrm{Ag} / \mathrm{Al}_{2} \mathrm{O}_{3}+\mathrm{Cu} / \mathrm{TiO}_{2}+\mathrm{Pt}$-supported catalysts, the reduction was $71 \%$ and $61 \%$ respectively at the high load engine. The same trend was obtained in the research published by Baskar and Kumar [71], who studied the effect of 
oxygen concentration in the intake air and diesel-water emulsion as fuel for combustion, performance and emission characteristics for a direct injection diesel engine. A reduction in $\mathrm{NO}_{\mathrm{x}}$ emission was observed in their work due to the reduction in combustion chamber temperature as the water concentration increased.

Another gas found in the emissions obtained in the combustion exhaust during the experiment was oxygen. Oxygen $\left(\mathrm{O}_{2}\right)$ was not perceived as a pollutant in this aspect. The necessity to examine the concentration of $\mathrm{O}_{2}$ in the exhaust was important to establish the benefits of bioethanol as being a carbon neutral and oxygenated fuel. The graph in Figure 8 presents the $\mathrm{O}_{2}$ emission in the exhaust gas, which shows that the concentration was the lowest in distillate diesel (DD) and high with respect to the increasing bioethanol volumetric ratio in the blending. The $\mathrm{O}_{2}$ concentration in the exhaust stream was pretty much stable and ranged from 17.95 to $19.25 \%$ from the high to low load input. Generally, the $\mathrm{O}_{2}$ emissions increased with the higher amount of bioethanol in diesel-biodieselbioethanol blended fuel as compared with the pure diesel. The results indicated that the $\mathrm{O}_{2}$ levels did not have any drastic change. In the lean and stoichiometric conditions where the amount of air is enough to sustain complete combustion efficiency, the levels of $\mathrm{O}_{2}$ are abundant, and the presence of additional $\mathrm{O}_{2}$ atoms in the bioethanol is directly noticed [59]. From Figure 8, it can be noticed that the oxygen concentration emissions were reduced with load for all the fuels modes. This was due to the fact that as the load increased, more $\mathrm{O}_{2}$ was used for complete combustion efficiency. The $\mathrm{O}_{2}$ emissions were reduced by $18.49 \%, 18.35 \%$, and $18.36 \%$, respectively with the blends DBE10, DBE15, and DBE20 compared with the diesel fuel at the full load of engine $(25 \mathrm{~kW})$.

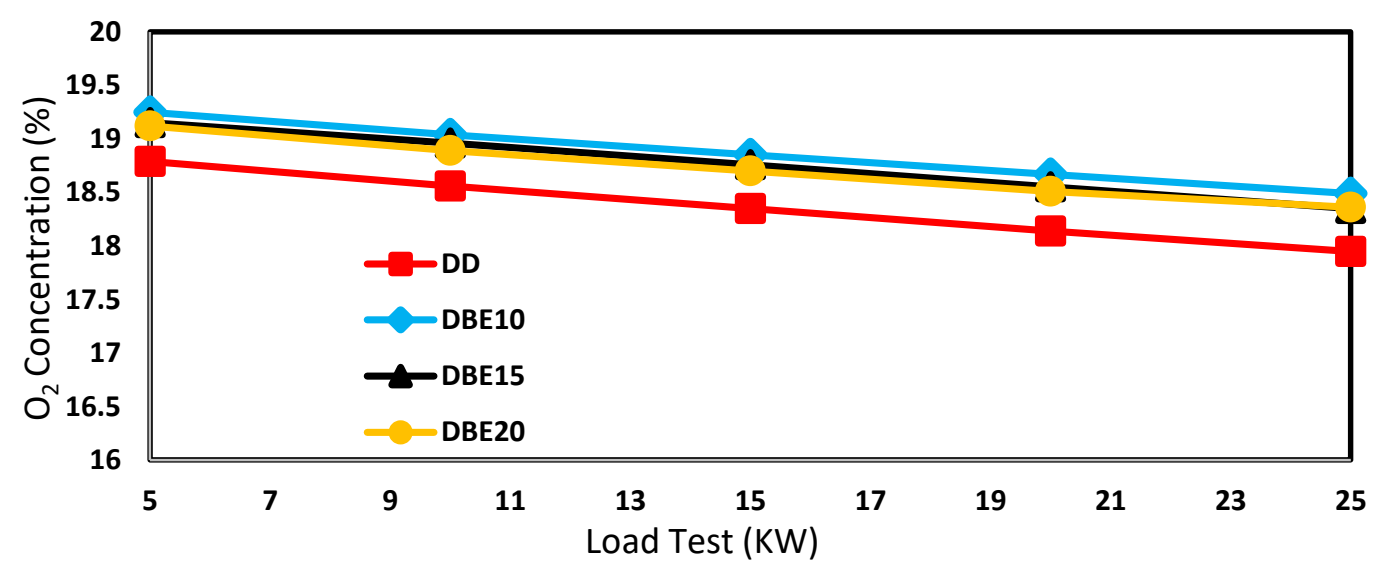

Figure 8. Variation of oxygen emissions from the micro gas turbine at different test loads for different blended fuels.

\section{CONCLUSIONS}

Renewable energy utilisation for power generation is still not wide spread and more data is needed on the performance of biofuel for gas turbine engines. The current study provided new information regarding the use of biofuels in micro turbines. The physicochemical characteristics of all the biofuels used must lie within the specifications for their use in micro gas turbines. Recent reports on the use of biodiesel in micro gas turbines have described problems associated with viscosity and density. In addition, the current study on the use of bioethanol in micro gas turbines has also demonstrated the drawbacks related to the increase in evaporation droplet time, which was explained in the part of the high latent heat of evaporation of ethanol. Hence, the blend ratio B80E20 (80\% 
biodiesel-20\% bioethanol) indicated by this research work was the most ideal blended fuel ratio to be applied in the micro gas turbine engine. This blend can replace diesel fuel, and therefore a $100 \%$ biofuel can be used in the existing gas turbine engines without the need of engine modifications. The results of this study are important to establish the limits of biofuel properties essential for the utilization in gas turbine application. Subsequently, the emissions test reported in this work also showed significant enhancement in emissions. This study has therefore shown that better returns that can be gained with the integration of the production of biodiesel and bioethanol by turning the waste glycerol, a by-product of biodiesel production, into fuel like bioethanol. Finally, it is worth mentioning that this study is among the few that has provided valuable data on the usage of biofuel for power generation using gas turbine. The usage of biodiesel and bioethanol (produced from waste glycerol) for power generation in micro gas turbine engine will also help to defray the cost of biodiesel production. Further work is necessary to evaluate the preliminary atomization in terms of the spray length and angle using thermal imaging for various blend fuels to mimic the actual condition that occurs in gas turbine prior to gas turbine application.

\section{ACKNOWLEDGMENTS}

The authors would like to thank the Malaysian Ministry of Education for valuable financial support through the Exploratory Research Grant Scheme No. 12012013. We also acknowledge the Sime Darby Malaysia, for supplying the (crude glycerol, biodiesel) and Universiti Tenaga Nasional for the research facilities.

\section{REFERENCES}

[1] Jaichandar S, Annamalai K. Jatropha oil methyl ester as diesel engine fuel - an experimental investigation. International Journal of Automotive and Mechanical Engineering. 2016;13:3248-61.

[2] Dubey P, Gupta R. Study of the performance and emission characteristics for a dual fuel powered single cylinder diesel engine. International Journal of Automotive and Mechanical Engineering. 2016;13:3373-88.

[3] Shukri MR, Rahman MM, Ramasamy D, Kadirgama K. Artificial neural network optimization modeling on engine performance of diesel engine using biodiesel fuel. International Journal of Automotive and Mechanical Engineering. 2015;11:2332-47.

[4] Blok K, Höhne N, Van Der Leun K, Harrison N. Bridging the greenhouse-gas emissions gap. Nature Climate Change. 2012;2:471.

[5] Wu Z, Xia X, Wang B. Improving building energy efficiency by multiobjective neighborhood field optimization. Energy and Buildings. 2015;87:45-56.

[6] Esen M, Yuksel T. Experimental evaluation of using various renewable energy sources for heating a greenhouse. Energy and Buildings. 2013;65:340-51.

[7] Dharma S, Ong HC, Masjuki H, Sebayang A, Silitonga A. An overview of engine durability and compatibility using biodiesel-bioethanol-diesel blends in compression-ignition engines. Energy Conversion and Management. 2016;128:66-81.

[8] Aziz Hairuddin A, Yusaf T, Wandel AP. Single-zone zero-dimensional model study for diesel-fuelled homogeneous charge compression ignition (HCCI) 
engines using Cantera. International Journal of Automotive and Mechanical Engineering. 2016;13:3309-28.

[9] Khalid A, Jaat N, Sapit A, Razali A, Manshoor B, Zaman I, et al. Performance and Emissions Characteristics of Crude Jatropha Oil Biodiesel Blends in a Diesel Engine. International Journal of Automotive and Mechanical Engineering. 2015;11:2447-57.

[10] Ghafoori M, Ghobadian B, Najafi G, Layeghi M, Rashidi A, Mamat R. Effect of nano-particles on the performance and emission of a diesel engine using biodieseldiesel blend. International Journal of Automotive and Mechanical Engineering. 2015;12:3097-108.

[11] Azad AK, Rasul MG, Giannangelo B, Islam R. Comparative study of diesel engine performance and emission with soybean and waste oil biodiesel fuels. International Journal of Automotive and Mechanical Engineering. 2015;12:286681.

[12] Loganathan M, Anbarasu A, Velmurugan A. Emission characteristics of jatrophadimethyl ether fuel blends on a DI diesel engine. International journal of scientific \& technology research. 2012;1:28-32.

[13] Mahgoub BK, Sulaiman S, Karim ZA. Performance study of imitated syngas in a dual-fuel compression ignition diesel engine. International Journal of Automotive and Mechanical Engineering. 2015;11:2282.

[14] Khalid A, Jaat N, Sapit A, Razali A, Manshoor B, Zaman I, et al. Performance and emissions characteristics of crude jatropha oil biodiesel blends in a diesel engine. International Journal of Automotive and Mechanical Engineering. 2015;11:2447.

[15] Hamada KI, Rahman MM, Ramasamy D, Noor MM, Kadirgama K. Numerical investigation of in-cylinder flow characteristics of hydrogen-fuelled internal combustion engine. Journal of Mechanical Engineering and Sciences. 2016;10:1782-802.

[16] Mohd Noor CW, Mamat R, Najafi G, Mat Yasin MH, Ihsan CK, Noor MM. Prediction of marine diesel engine performance by using artificial neural network model. Journal of Mechanical Engineering and Sciences. 2016;10:1917-30.

[17] Kettner M, Dechent S, Hofmann M, Huber E, Arruga H, Mamat R, et al. Investigating the influence of water injection on the emissions of a diesel engine. Journal of Mechanical Engineering and Sciences. 2016;10:1863-81.

[18] Cavarzere A, Morini M, Pinelli M, Spina PR, Vaccari A, Venturini M. Experimental analysis of a micro gas turbine fuelled with vegetable oils from energy crops. Energy Procedia. 2014;45:91-100.

[19] De Paepe W, Contino F, Delattin F, Bram S, De Ruyck J. Optimal waste heat recovery in micro gas turbine cycles through liquid water injection. Applied Thermal Engineering. 2014;70:846-56.

[20] Ivaniš GR, Radović IR, Veljković VB, Kijevčanin ML. Thermodynamic properties of biodiesel and petro-diesel blends at high pressures and temperatures. Experimental and modeling. Fuel. 2016;184:277-88.

[21] Gao Y, Deng J, Li C, Dang F, Liao Z, Wu Z, et al. Experimental study of the spray characteristics of biodiesel based on inedible oil. Biotechnology Advances. 2009;27:616-24.

[22] Park SH, Suh HK, Lee CS. Nozzle flow and atomization characteristics of ethanol blended biodiesel fuel. Renewable energy. 2010;35:144-50. 
[23] Mohod TR, Bhansali S, Moghe S, Kathoke T. Preheating of biodiesel for the improvement of the performance characteristics of di engine: A Review. International Journal of Engineering Research and General Science. 2014;2:74753.

[24] Kun-Balog A, Sztankó K. Reduction of pollutant emissions from a rapeseed oil fired micro gas turbine burner. Fuel Processing Technology. 2015;134:352-9.

[25] Dubey P, Gupta R. Study of the performance and emission characteristics for a dual fuel powered single cylinder diesel engine. International Journal of Automotive \& Mechanical Engineering. 2016;13.

[26] Yasin MHM, Mamat R, Aziz A, Yusop AF, Ali MH. Investigation on combustion parameters of palm biodiesel operating with a diesel engine. Journal of Mechanical Engineering and Sciences. 2015;9:1714-26.

[27] Said NH, Ani FN, Said MFM. Review of the production of biodiesel from waste cooking oil using solid catalysts. Journal of Mechanical Engineering and Sciences. 2015;8:1302-11.

[28] Hoque N, Mourshed M, Das BK. Performance and emission comparison of Karanja (pongamia pinnata), Pithraj (aphanamixis polystachya), Neem (azadira chtaindica) and Mahua (madhuca longofolia) seed oil as a potential feedstock for biodiesel production in Bangladesh. International Journal of Automotive and Mechanical Engineering. 2015;12:2967-82.

[29] Hasan MM, Rahman MM, Kadirgama K. A review on homogeneous charge compression ignition engine performance using biodiesel-diesel blend as a fuel. International Journal of Automotive and Mechanical Engineering. 2015;11:2199211.

[30] Selim MY. Reducing the viscosity of Jojoba Methyl Ester diesel fuel and effects on diesel engine performance and roughness. Energy Conversion and Management. 2009;50:1781-8.

[31] Yilmaz N, Sanchez TM. Analysis of operating a diesel engine on biodieselethanol and biodiesel-methanol blends. Energy. 2012;46:126-9.

[32] Yoon SH, Park SH, Suh HK, Lee CS. Effect of biodiesel-ethanol blended fuel spray characteristics on the reduction of exhaust emissions in a common-rail diesel engine. Journal of Energy Resources Technology. 2010;132:042201.

[33] Campos-Fernández J, Arnal JM, Gómez J, Dorado MP. A comparison of performance of higher alcohols/diesel fuel blends in a diesel engine. Applied energy. 2012;95:267-75.

[34] Mwangi JK, Lee W-J, Chang Y-C, Chen C-Y, Wang L-C. An overview: Energy saving and pollution reduction by using green fuel blends in diesel engines. Applied Energy. 2015;159:214-36.

[35] Saifuddin N, Refal H. Optimization of fermentation parameters for bioethanol production from waste glycerol by microwave induced mutant Escherichia coli. Research Journal of Pharmaceutical, Biological and Chemical Sciences. 2015;6:1449-61.

[36] Tomanee P. Cassava-based adsorbent for removing water from ethanol vapor. AIChE 2008 Annual Meeting, Philadelphia, PA, USA2008.

[37] Lefebvre AH, McDonell VG. Atomization and sprays: CRC press; 2017.

[38] Bolszo CD. Investigation of atomization, mixing and pollutant emissions for a microturbine engine. The UCI Undergraduate Research Journal. 2005;8:13-22.

[39] Standard A. Power test code for fired steam generators. ASME Standard PTC-41. USA: ASME; 1998. 
[40] Lefebvre AH. Airblast atomization. Progress in Energy and Combustion Science. 1980;6:233-61.

[41] Anwar ZM TE. Investigation of various biodiesel blend spray characteristics in micro turbine. Journal of Advanced Science and Engineering Research. 2014;4:184-95.

[42] Guan L, Tang C, Yang K, Mo J, Huang Z. Effect of di-n-butyl ether blending with soybean-biodiesel on spray and atomization characteristics in a common-rail fuel injection system. Fuel. 2015;140:116-25.

[43] Farouk T DF. Studies of the combustion of drops in a fuel spray - the burning of single drops of fuel. Symposium (International) on Combustion: Elsevier; 1953. p. 818-30.

[44] Gupta K, Rehman A, Sarviya R. Bio-fuels for the gas turbine: A review. Renewable and Sustainable Energy Reviews. 2010;14:2946-55.

[45] Chong CT, Hochgreb S. Spray combustion characteristics of palm biodiesel. Combustion Science and Technology. 2012;184:1093-107.

[46] Benjumea P, Agudelo J, Agudelo A. Basic properties of palm oil biodiesel-diesel blends. Fuel. 2008;87:2069-75.

[47] Zhang M, Xu M, Zeng W, Zhang G, Zhang Y, Cleary DJ. Characterization of methanol and ethanol sprays using Mie-scattering and laser induced fluorescence under engine cold-start conditions. 13th Annual Conf on Liquid Atomization and Spray Systems-Asia; 2009.

[48] Bagul AD RH, Chaudhari SA, Waghodekar SV. Performance Testing of engine under alcohol blending with data acquisition system. International Journal of Emerging Technology and Advanced Engineering. 2016;6:238-43.

[49] Iranmanesh M. Experimental investigations about the effect of new combination of biofuels on simultaneous reduction of NOx and smoke emissions in DI-diesel engine. International Journal of Automotive Engineering. 2013;3(2):379-92.

[50] Attallaa M, Solimana A, Torkyb MA. Engine Performance and Exhaust Emissions of an SI Engine Using Acetic Acid, Ethanol, and Gasoline Blended Fuel. 2013.

[51] Sileghem L, Casier B, Coppens A, Vancoillie J, Verhelst S. Influence of water content in ethanol-water blends on the performance and emissions of an SI engine. Fisita World Automotive Congress2014.

[52] Zhu L, Cheung C, Zhang W, Huang Z. Combustion, performance and emission characteristics of a DI diesel engine fueled with ethanol-biodiesel blends. Fuel. 2011;90:1743-50.

[53] Yilmaz N. Comparative analysis of biodiesel-ethanol-diesel and biodieselmethanol-diesel blends in a diesel engine. Energy. 2012;40:210-3.

[54] Hulwan DB, Joshi SV. Performance, emission and combustion characteristic of a multicylinder DI diesel engine running on diesel-ethanol-biodiesel blends of high ethanol content. Applied Energy. 2011;88:5042-55.

[55] Prabakaran B, Udhoji A. Experimental investigation into effects of addition of zinc oxide on performance, combustion and emission characteristics of dieselbiodiesel-ethanol blends in CI engine. Alexandria Engineering Journal. 2016;55:3355-62.

[56] Tse H, Leung C, Cheung C. Performances, emissions and soot properties from a diesel-biodiesel-ethanol blend fuelled engine. Advances of Automobile Engineering S1: 005:1-11. 
[57] Banapurmath N, Khandal S, Swamy RL, Chandrashekar T. Alcohol (ethanol and diethyl ethyl ether)-diesel blended fuels for diesel engine applications-a feasible solution. Advances in Automobile Engineering. 2015;4(1) 1000117.

[58] Krishna R, Bandewar AG, Dongare VK. Experimental Investigations of blending diethyl ether in karanja vegetable oil using a multi-cylinder diesel engine. International Journal of Research and Innovative Technology. 2015;1:70-3.

[59] Anand R KG, Karthikeyan PA. Study of the performance emission and combustion characteristics of a di diesel engine using waste cooking oil methyl ester-ethanol blends. Proceedings of the ASME 2012 International Mechanical Engineering Congress \& Exposition. 2012;1:1-7.

[60] Cheenkachorn K, Fungtammasan B. Biodiesel as an additive for diesohol. International Journal of Green Energy. 2009;6:57-72.

[61] Subbaiah GV, Gopal KR, Hussain SA. The effect of biodiesel and bioethanol blended diesel fuel on the performance and emission characteristics of a direct injection diesel engine. Iranica Journal of Energy and Environment. 2010;1:21121.

[62] Deshpande SS CS, Pawar AA. . Experimental evaluation of diesel engine performance and emissions using diesel/biodiesel/ ethanol blend fuel. International Journal of Emerging Technology and Advanced Engineering. 2015;5:263-71.

[63] Farkade H, Pathre A. Experimental investigation of methanol, ethanol and butanol blends with gasoline on SI engine. International Journal of Emerging Technology and Advanced Engineering. 2012;2:205-15.

[64] Kumar BM, Prabakaran B. experimental investigation on performance and emission characteristics of diesel-ethanol-biodiesel blend in diesel engine. Parameters. International Journal Of Engineering Sciences \& Research Technology. 2015;20:347-52.

[65] Barabas I, Todoruţ A, Băldean D. Performance and emission characteristics of an CI engine fueled with diesel-biodiesel-bioethanol blends. Fuel. 2010;89:382732.

[66] Bhale PV, Deshpande NV, Thombre SB. Improving the low temperature properties of biodiesel fuel. Renewable Energy. 2009;34:794-800.

[67] Palash S, Kalam M, Masjuki H, Arbab M, Masum B, Sanjid A. Impacts of NOx reducing antioxidant additive on performance and emissions of a multi-cylinder diesel engine fueled with Jatropha biodiesel blends. Energy Conversion and Management. 2014;77:577-85.

[68] Shahir S, Masjuki H, Kalam M, Imran A, Ashraful A. Performance and emission assessment of diesel-biodiesel-ethanol/bioethanol blend as a fuel in diesel engines: A review. Renewable and Sustainable Energy Reviews. 2015;48:62-78.

[69] Mofijur M, Rasul M, Hyde J. Recent developments on internal combustion engine performance and emissions fuelled with biodiesel-diesel-ethanol blends. Procedia Engineering. 2015;105:658-64.

[70] Xiaoyan S, Yunbo Y, Hong H, Shuai S, Hongyi D, Rulong L. Combination of biodiesel-ethanol-diesel fuel blend and SCR catalyst assembly to reduce emissions from a heavy-duty diesel engine. Journal of Environmental Sciences. 2008;20:177-82.

[71] Baskar P, Kumar AS. Experimental investigation on performance characteristics of a diesel engine using diesel-water emulsion with oxygen enriched air. Alexandria Engineering Journal. 2017;56:137-46. 